\title{
РОЛЬ ОКСИДАТИВНОГО І НІТРООКСИДАТИВНОГО СТРЕСУ В ПАТОГЕНЕЗІ ГЕНЕРАЛІЗОВАНОГО ПАРОДОНТИТУ НА ФОНІ ХРОНІЧНОГО ГАСТРИТУ
}

Метою даної роботи було дослідити в експерименті біохімічні механізми розвитку ліпополісахаридного запалення тканин пародонта на фроні хронічного запального ураження слизової оболонки шлунка. Дослідження проведено на білих щурах, у яких викликали запалення пародонта введенням протягом 2 тижнів у тканини ясен по 40 мікролітрів (1 мг/мл) ліпополісахариду E. Coli. Хронічний атрофрічний гастрит викликали шляхом інтрагастрального введення протягом 6 тижнів 2 \% саліцилату натрію і заміни питної води на 20 мМ деоксихолат натрію. При ліпополісахаридному пародонтиті в тканинах пародонта і крові зростав вміст ТБК-активних продуктів та окисномодифрікованих білків, знижувалися активність супероксиддисмутази і вміст відновленого глутатіону, підвищувались загальна активність NO-синтази і рівень NO. У тварин з пародонтитом, що розвивався на фроні хронічного гастриту, явища оксидативного та нітрооксидативного стресу були значно більш вираженими, ніж у щурів, у яких гастрит не моделювали. Зроблено висновок, що хронічний гастрит суттєво посилює явища оксидативного і нітрооксидативного стресу в тканинах пародонта при його ураженні бактеріальним ендотоксином ліпополісахаридом.

КЛЮчОВІ СЛОВА: пародонтит, хронічний гастрит, оксидативний та нітрооксидативний стрес.

ВСТУП. Епідеміологічні дані свідчать про високу частоту пародонтиту в осіб з патологією шлунково-кишкового тракту, зокрема з хронічними гастритами. Серед пацієнтів із захворюваннями органів травлення патологічні зміни тканин пародонта зустрічаються у 88-92 \% випадків [1]. Відомо, що етіологічним фрактором пародонтиту є патогенні мікроорганізми. Розвиток запальних захворювань завжди тісно пов'язаний з активізацією вільнорадикальних реакцій у тканинах та порушенням фрункціонування системи антиоксидного захисту, тобто з так званим оксидативним стресом [2]. При запальному ураженні такожзазвичай має місце гіперекспресія індуцибельної фрорми синтази оксиду азоту (iNOS), що призводить до продукування надмірної кількості NO, який може відігравати роль важливого есректора в механізмах розвитку запалення, генерованого бактеріальним ендотоксином. Тобто при запаленні розвивається так званий нітрооксидативний стрес [3]. Механізми, що лежать в основі впливу хвороб шлунка на патогенез пародонтиту, особливості перебігу (с) О. С. Беденюк, М. М. Корда, 2016. поєднаної патології на сьогодні все ще потребують детальнішого вивчення. Зокрема, оцінка інтенсивності оксидативного і нітрооксидативного стресу, який певною мірою детермінує вираження резорбтивних процесів у сполучній тканині, набуває важливого значення як у вивченні механізмів формування, так і в розробці методів лікування пародонтиту, асоційованого 3 хронічним гастритом.

Метою даної роботи було дослідити в експерименті біохімічні механізми розвитку ліпополісахаридного запалення тканин пародонта на ороні хронічного запального ураження слизової оболонки шлунка.

МЕТОДИ ДОСЛІДЖЕННЯ. ДЛЯ ДОслідів використали 40 безпородних щурів-самців масою 160-180 г, яких утримували на стандартній дієті. Усіх тварин поділили на чотири групи: 1-ша контроль (інтактні щури); 2-га - щури, в яких викликали хронічний гастрит шляхом інтрагастрального введення протягом 6 тижнів $2 \%$ саліцилату натрію, питну воду в цій групі тварин заміняли на 20 мМ деоксихолат натрію; 3-тя - 
тварини, в яких викликали запалення пародонта (протягом 2 тижнів через день вводили в тканиниясенпо 40 мікролітрів (1 мг/мл) ліпополісахариду E. Coli (ЛПC)); 4-та-щури, яким після закінчення курсу введення саліцилату натрію вводили протягом 2 тижнів ЛПС у вищезазначеній дозі. Розвиток атрофрічного гастриту підтверджували гістологічні дослідження. Відбирали зразки кардіальної, фрундальної та пілоричної частин шлунка, які обробляли стандартними методами. Зразки забарвлювали гематоксиліном та еозином. Тварин виводили з експерименту шляхом декапітації під тіопенталовим наркозом. У гомогенаті тканин пародонта визначали загальну активність NO-синтази [4], в пародонті й крові рівень нітратів і нітритів (NO $)$ [5], ТБК-активних продуктів (ТБК-АП) [6], окисномодиорікованих білків (ОМБ) [7], активність супероксиддисмутази (СОД) [8], каталази (КТ) [9] та вміст відновленого глутатіону (ГSH) [10]. У плазмі крові також визначали вміст церулоплазміну (ЦП) [11] і загальну антиоксидну активність (3АА) [12].

Результати виражали як середнє $\mathrm{SEM} 310$ експериментів. Статистичний аналіз виконували, використовуючи стандартні статистичні програми і t-критерій Стьюдента. Зміни p<0,05 розглядали як статистично достовірні.

РЕЗУЛЬТАТИ Й ОБГОВОРЕННЯ. ДЛЯ ПіДтвердження розвитку гастриту в щурів, яким інтрагастрально вводили протягом 6 тижнів 2 \% саліцилат натрію, а питну воду заміняли на 20 мМ деоксихолат натрію, проводили морфологічні дослідження тканини стінки шлунка. Спостерігали зменшення товщини слизової оболонки порівняно з контролем і часткове розгладження макроскопічних складок шлунка. Залози розташовувались невпорядковано, їх кількість зменшувалась порівняно з контролем. Відзначали також проростання сполучної тканини в основу залоз і лімсратичну інсільтрацію. Наведені зміни свідчать про розвиток хронічного атрофрічного гастриту в щурів під впливом саліцилату і деоксихолату натрію.

Одним із неспецифрічних механізмів розвитку будь-яких запальних захворювань, у тому числі й тканин пародонта, є активація процесів вільнорадикального окиснення. Про інтенсивність процесів ліпопероксидації та окисної модисрікації білків ми судили за вмістом у сироватці крові й пародонті тварин ТБК-активних продуктів, що утворюються при окисненні ненасичених жирних кислот, і альдегідо- та кетонопохідних, які утворюються при дії активних радикалів на амінокислотні залишки в молекулах білків. Як видно 3 даних, наведених у таблицях 1 і 2, бактеріальний ендотоксин ліпополісахарид викликав достовірне зростання вмісту ТБК-АП як у сироватці крові (в 1,2 раза), так і в пародонті (в 1,4 раза). У щурів із гастритом також спостерігали підвищення рівня ТБК-АП, але тільки в сироватці крові (в 1,6 раза). Моделювання генералізованого пародонтиту викликало окисну модифікацію нейтральних і лужних амінокислот. Рівень альдегідо- і кетонопохідних нейтрального характеру, які визначаються за вмістом 2,4-динітрофренілгідразонів при довжині хвилі 310 нм, у тканинах пародонта підвищувався в 1,6 раза порівняно зі здоровими тваринами, а альдегідо- і кетонопохідних основного характеру, що визначаються за вмістом 2,4-динітрофренілгідразонів при довжині хвилі 430 нм, - у 2,1 раза. У сироватці крові ці показники зростали, відповідно, в 1,3 і 1,5 раза. У щурів із хронічним атрофрічним гастритом інтенсивність окисної модифрікації білків не змінювалася достовірно в тканинах пародонта, проте підвищувалась у 2,2 і 2,5 раза в сироватці крові. Найбільшою мірою інтенсивність оксидативного стресу зростала у тварин із хронічним гастритом, в яких моделювали ліпополісахаридне запалення пародонта. У цієї групи щурів активність реакцій вільнорадикального окиснення жирних кислот підвищувалася у 2,2 раза в крові та в 1,8 раза в пародонті, а вільнорадикального окиснення білків - у 3,1-3,6 і 2,5-2,7 раза відповідно.

Швидкість радикальних реакцій у біологічних тканинах детермінується фрункціональним станом системи антиоксидного захисту. В роботах $[13,14]$ було показано, що при пародонтиті антиоксидна система організму зазнає суттєвих порушень. Результати наших досліджень (табл. 2) свідчать про те, що при введенні тваринам ЛПС активність СОД, який є одним з основних антиоксидних орерментів організму, зменшувалася у тканинах пародонта в 1,6 раза. У щурів з пародонтитом також достовірно знижувався вміст ГSH у тканинах ясен. Водночас моделювання гастриту не викликало значущих змін показників фрункціонування антиоксидної системи у тканинах пародонта.

Введення тваринам ЛПС не призводило до змін фуункціонального стану системи антиоксидного захисту в крові. У щурів із хронічним гастритом активність КТ і вміст ЦП у сироватці крові достовірно зростали (відповідно, в 1,8 та 1,2 раза), тоді як рівень ГSН і ЗАА сироватки крові, навпаки, знижувалися (в 1,3 та 1,6 раза).

Максимальнізмінипоказників функціонування антиоксидної системи, як і параметрів, що характеризують інтенсивність окиснювальних процесів, зафріксовано у тварин з ліпополісахаридним запаленням на фроні хронічного гастриту. В щурів 4-ї групи ЗАА плазми була достовірно нижчою, 
Таблиця 1 - Показники інтенсивності оксидативного стресу в сироватці крові щурів 3 ліпополісахаридним пародонтитом на фоні хронічного гастриту (M $\pm m, n=10)$

\begin{tabular}{|c|c|c|c|c|}
\hline \multirow{2}{*}{ Показник } & \multicolumn{4}{|c|}{ Група тварин } \\
\hline & контроль & пародонтит & гастрит & пародонтит+гастрит \\
\hline ТБК-АП, мКмоль/л & $40,70 \pm 2,65$ & $55,08 \pm 3,05^{*}$ & $69,70 \pm 4,38^{*}$ & $97,25 \pm 5,20$ *\# \\
\hline ОМБ $_{310}$, мкмоль/мг білка & $0,85 \pm 0,06$ & $1,18 \pm 0,07^{*}$ & $1,90 \pm 0,15^{\star}$ & $2,68 \pm 0,19^{\star \#+}$ \\
\hline $\mathrm{OMБ}_{430}$, мкмоль/мг білка & $0,62 \pm 0,03$ & $0,96 \pm 0,06^{*}$ & $1,60 \pm 0,08^{*}$ & $2,25 \pm 0,19^{\star \#+}$ \\
\hline КТ, мкат/л & $0,50 \pm 0,02$ & $0,64 \pm 0,03$ & $0,93 \pm 0,05^{\star}$ & $1,15 \pm 0,07^{\star \#}$ \\
\hline ЦП, г/л & $0,33 \pm 0,01$ & $0,28 \pm 0,02$ & $0,40 \pm 0,02^{*}$ & $0,47 \pm 0,03^{\star \#}$ \\
\hline ГSН, ммоль/л & $2,70 \pm 0,16$ & $3,05 \pm 0,18$ & $1,96 \pm 0,10^{*}$ & $1,78 \pm 0,08^{\star *}$ \\
\hline $\begin{array}{l}\text { ЗАА, \% гальмування } \\
\text { утворення ТБК-АП }\end{array}$ & $60,20 \pm 4,12$ & $56,15 \pm 3,80$ & $36,05 \pm 2,94^{*}$ & $24,85 \pm 2,20^{\star \#+}$ \\
\hline
\end{tabular}

Примітка. Тут і в наступних таблицях: * - зміни достовірні порівняно з показниками інтактних тварин; \# - зміни достовірні порівняно з показниками тварин з пародонтитом; ${ }^{\dagger}-3$ міни достовірні порівняно 3 показниками тварин із гастритом.

Таблиця 2 - Показники інтенсивності оксидативного стресу в тканинах пародонта щурів 3 ліпополісахаридним пародонтитом на фоні хронічного гастриту (M $\pm m, n=10)$

\begin{tabular}{|c|c|c|c|c|}
\hline \multirow{2}{*}{ Показник } & \multicolumn{4}{|c|}{ Група тварин } \\
\hline & контроль & пародонтит & гастрит & пародонтит+гастрит \\
\hline ТБК-АП, мкмОЛЬ/кг & $2,83 \pm 0,18$ & $4,18 \pm 0,20^{*}$ & $2,65 \pm 0,16$ & $5,15 \pm 0,21^{\text {*\#+ }}$ \\
\hline ОМБ $_{310}$, мкмоль/мг білка & $3,96 \pm 0,24$ & $6,68 \pm 0,41^{*}$ & $4,13 \pm 0,22$ & $9,94 \pm 0,54^{\star \#+}$ \\
\hline $\mathrm{OMБ}_{430}$, мкмоль/мг білка & $2,75 \pm 0,18$ & $5,80 \pm 0,38^{*}$ & $2,90 \pm 0,20$ & $7,55 \pm 0,40^{\star \#+}$ \\
\hline СОД, оД. & $0,23 \pm 0,01$ & $0,14 \pm 0,01^{*}$ & $0,19 \pm 0,02$ & $0,10 \pm 0,008^{\star \#+}$ \\
\hline КТ, мкат/мг білка & $1,35 \pm 0,10$ & $1,27 \pm 0,08$ & $1,21 \pm 0,09$ & $0,80 \pm 0,05^{\star \#+}$ \\
\hline ГSН, ммоль/кг & $195,2 \pm 9,90$ & $116,4 \pm 7,85^{\star}$ & $155,2 \pm 8,66$ & $82,44 \pm 5,50^{* \#+}$ \\
\hline
\end{tabular}

ніж така у тварин тільки з пародонтитом або 3 гастритом. Активність СОД, КТ і вміст ГSH у пародонті при поєднаній патології зменшувалися, відповідно, в 2,1, 1,7 та 2,2 раза порівняно 3 контролем і також були достовірно нижчими порівняно з відповідними показниками у тварин 2-ї чи 3-ї групи.

Отже, всі вищенаведені результати дозволяють прийти до висновку, що активація вільнорадикальних реакцій є важливим неспецифічним механізмом розвитку запалення тканин пародонта, викликаного токсином грамнегативної мікрофрлори ліпополісахаридом. Особливого значення оксидативний стрес набуває за умов, коли пародонтит розвивається на фроні хронічного атрофрічного гастриту.

Важливим медіатором розвитку запалення будь-якої етіології є оксид азоту (NO). NO - короткоживучий радикал, що впливає на фрізіологічні та патологічні процеси в кожному органі й тканині. За нормальних умов конститутивна фрорма NO-синтази фрункціонально активна в ендотеліальних клітинах слизової оболонки і капілярів, де вона продукує відносно невелику кількість NO, що регулює персузію крові, в тому числі й у тканинах пародонта. Проте при запальному ураженні має місце гіперекспресія iNOS, що призводить до продукування великої кількості $\mathrm{NO}$, який може відігравати роль важливого ефектора в механізмах розвитку запалення, генеро- ваного бактеріальним ендотоксином. Таке гіперпродукування NO і його активних похідних, яке спостерігають при запальній відповіді, спричиняє інгібування функції фрерментів, пошкодження ДНК, активацію вільнорадикальних процесів. Тобто при запаленні розвивається так званий нітрооксидативний стрес.

Як свідчать результати досліджень, наведені в таблиці 3, при введенні щурам ЛПС загальна активність NO-синтази різко (у 2,2 раза) підвищувалася порівняно 3 контролем. У тварин 4-ї групи, яким ЛПС вводили на фроні гастриту, активність фрерменту зростала в 3 рази. Необхідно зазначити, що при поєднаній патології загальна активність NO-синтази була достовірно вищою як порівняно з групою тварин тільки 3 пародонтитом, так і порівняно 3 групою щурів із гастритом. Імовірно, мала місце сумація стимуляційних ефректів ЛПС і прозапальних фракторів, що утворюються в стінці шлунка при гастриті, на активність NO-синтази.

Очевидно, саме активацією NO-синтази можна пояснити отримані нами результати, які свідчать про достовірне збільшення рівня метаболітів оксиду азоту - нітратів і нітритів - у сироватці крові й пародонті щурів, яким вводили ЛПС. Так, вміст $\mathrm{NO}_{x}$ у сироватці крові тварин 3 пародонтитом зростав в 1,3 раза порівняно 3 контролем, а в тканинах пародонта - в 1,4 раза. Як і в попередньому випадку, найбільш виражені 
Таблиця 3 - Активність NO-синтази у тканинах пародонта і вміст нітратів та нітритів (NO) у сироватці крові й пародонті щурів з ліпополісахаридним пародонтитом на фоні хронічного гастриту $(M \pm m, n=10)$

\begin{tabular}{|c|c|c|c|}
\hline \multirow{3}{*}{ Група тварин } & \multicolumn{3}{|c|}{ Показник } \\
\hline & \multirow{2}{*}{$\begin{array}{c}\text { NO-синтаза, } \\
\text { нмоль/мг білка·хв }\end{array}$} & \multicolumn{2}{|c|}{$\mathrm{NO}_{\mathrm{x}}$} \\
\hline & & сироватка крові, ммоль/л & пародонт, ммоль/кг \\
\hline Контроль & $0,25 \pm 0,02$ & $2,34 \pm 0,13$ & $0,81 \pm 0,06$ \\
\hline Пародонтит & $0,56 \pm 0,04^{*}$ & $3,25 \pm 0,15^{\star}$ & $1,15 \pm 0,07^{*}$ \\
\hline Гастрит & $0,32 \pm 0,03$ & $2,60 \pm 0,12$ & $0,90 \pm 0,05$ \\
\hline Пародонтит+гастрит & $0,78 \pm 0,05^{\star \#+}$ & $4,09 \pm 0,18^{\star \#+}$ & $1,58 \pm 0,08^{\star \#+}$ \\
\hline
\end{tabular}

зміни концентрації нітратів і нітритів засріксовано в щурів 3 поєднаною патологією: в сироватці крові - в 1,7 раза, в пародонті - у 2 рази. Як у крові, так і в пародонті щурів 4-ї групи показники вмісту $\mathrm{NO}_{x}$ були достовірно вищими за такі у тварин тільки з гастритом і за такі у тварин 3 пародонтитом без гастриту.

Отже, отримані результати дозволяють стверджувати, що гіперпродукування NO, поряд 3 активацією кисневих вільнорадикальних реакцій, є однією з ключових ланок патогенезу пародонтиту, що розвивається на фроні хронічного гастриту. Відомо, що вироблення макрофрагами NO при запаленні пародонта стимулює разом 3 іншими радикалами реакції фрагоцитозу [15], тобто NO також може виконувати корисну фрункцію при пародонтиті, виступаючи неспециорічним фрактором захисту від бактерій. Водночас десріцит NO сприяє розмноженню збудників у тканинах пародонта, що призводить до хронізації патологічного процесу. Проте різке збільшення рівня NO відіграє негативну роль, оскільки започатковує ряд вільнорадикальних механізмів, що викликають деструкцію тканин, у тому числі й сполучної тканини пародонта. Отримане нами суттєве зростання рівня $\mathrm{NO}_{x}$ у крові й пародонті при дії ЛПС на фроні хронічного гастриту можна пояснити тим фрактом, що при запальному ураженні слизової оболонки шлунка утворюється велика кількість ендотоксинів, що стимулюють вироблення цитокінів, які здатні стимулювати iNOS, у тому числі й у пародонті.

ВИСНОВОК. Нітрооксидативний стрес, паралельно з активацією кисневих вільнорадикальних процесів, є важливою ланкою в ланцюгу патобіохімічних механізмів розвитку пародонтиту на фроні хронічного гастриту.

\section{СПИСОК ЛІТЕРАТУРИ}

1. Манащук Н. В. Взаємозв'язок патології пародонта та патології шлунково-кишкового тракту / Н. В. Манащук, Н. В. Чорній, В. В. Шманько // Клініч. стоматологія. - 2011. - № 1-2. - С. 23-27.

2. Колодницька Г. Б. Перебіг ліпополісахаридного запалення ясен при інсулінозалежному цукровому діабеті / Г. Б. Колодницька, М. М. Корда // Мед. хімія. 2011. - 13, № 3 (48). - С. 91-91.

3. Колодницька Г. Б. Патогенетичне обґрунтування доцільності інгібування iNOS при запаленні тканин пародонта на фоні цукрового діабету / Г. Б. Колодницька, В. М. Коропчук, М. М. Корда // Мед. хімія. 2013. - 15, № 1 (54). - C. 90-95.

4. $\mathrm{N}^{\omega}$-Hydroxy-L-arginine is an intermediate in the biosynthesis of nitric oxide from L-arginine / D. Stuehr, N. S. Kwon, C. Nathan, O. Griffiths // J. Biol. Chem. 1991. - 266. - P. 6259-6263.

5. A spectrophotometric method for the direct detection and quantitation of nitric oxide, nitrite, and nitrate in cell culture media / L. Ridnour, J. E. Sim, M. Hayward [et al.] // Anal. Biochem. - 2000. - 281. - P. 223-229.

6. Андреева Л. И. Модисрикация метода определения перекисей липидов в тесте с тиобарбитуровой кислотой / Л. И. Андреева, Л. А. Кожемякин, А. А. Кишкун // Лаб. дело. - 1988. - № 11. - С. 41-43.

7. Мещишен І. Ф. Методвизначення окислювальної модифікації білків плазми (сироватки) крові / І. Ф. Мещишен // Буковинський мед. вісн. - 1998. - 2, № 1. C. $156-158$.

8. Чевари С. Роль супероксиддисмутазы в окислительных процессах клетки и метод определения ее в биологическом материале / С. Чевари, И. Чаба, Й. Секей // Лаб. дело. - 1985. - № 11. - С. 678-681.

9. Метод определения активности каталазы / М. А. Королюк, Л. И. Иванова, И. Г. Майорова, В. Е.Токарев // Лаб. дело. - 1988. - № 1. - С. 16-19.

10. Ellman G.L. Tissue sulfhydryl groups // Arch. of Bioch. and Biophys. - 1959. - 82. - P. 70-77.

11. Колб В. Г. Справочник по клинической химии / В. Г. Колб, В. С. Камышников. - Минск : Беларусь, 1982. $-311 \mathrm{c}$.

12. Assay using brain homogenate for measuring the antioxidant activity of biological fluids / J. Stock, J. M. Gutteridge, R. J. Sharp, I. L. Dormandy // Clin. Sci. and Mol. Med. - 1974. - 47. - P. 215-222.

13. Косенко К. Н. Показатели свободнорадикального окисления липидов и антиоксидантной защиты 
в ротовой жидкости больных генерализованным пародонтитом разных возрастных групп / К. Н. Косенко, А. А. Седлецкая, Т. П. Терешина // Вісн. стоматол. 2004. - № 4. - C. 27-30.

14. Плотникова В. Г. Влияние лизоцимсодержащих препаратов на прооксидантно-антиоксидантный статус крыс при экспериментальном пародонтите /
В. Г. Плотникова, О. А. Макаренко // Вісн. стоматол. 2006. - № 2. - C. 20-25.

15. Evaluation of the activity of leukocytes during experimental periodontitis in the monkey / G. Gagnot, J. F. Michel, E. Legall [et al.] // J. Biol. Buccale. - 1988. 16 (1). - P. 25-30.

\author{
ТЕРНОПОЛЬСКИЙ ГОСУДАРСТВЕННЫЙ МЕДИЦИНСКИЙ УНИВЕРСИТЕТ ИМЕНИ И. Я. ГОРБАЧЕВСКОГО
}

\title{
РОЛЬ ОКСИДАТИВНОГО И НИТРООКСИДАТИВНОГО СТРЕССА В ПАТОГЕНЕЗЕ ГЕНЕРАЛИЗОВАННОГО ПАРОДОНТИТА НА ФОНЕ ХРОНИЧЕСКОГО ГАСТРИТА
}

\begin{abstract}
Резюме
Целью данной работы было исследовать в эксперименте биохимические механизмы развития липополисахаридного воспаления тканей пародонта на фоне хронического воспалительного поражения слизистой оболочки желудка. Исследование проведено на белых крысах, у которых вызывали воспаление пародонта введением на протяжении 2 недель в ткани десен по 40 микролитров (1 мг/мл) липополисахарида E. Coli. Хронический атрофический гастрит вызывали путем интрагастрального введения на протяжении 6 недель 2 \% салицилата натрия и замены питьевой воды на 20 мМ деоксихолат натрия. При липополисахаридном пародонтите в тканях пародонта и крови возрастало содержание ТБК-активных продуктов и окислительномодифицированных белков, снижались активность супероксиддисмутазы и содержание восстановленного глутатиона, повышались общая активность NO-синтазы и уровень $N_{x}$ У животных с пародонтитом, который развивался на фроне хронического гастрита, явления оксидативного и нитрооксидативного стресса были значительно более выражены, чем у крыс, у которых гастрит не моделировали. Сделан вывод, что хронический гастрит существенно усиливает явления оксидативного и нитрооксидативного стресса в тканях пародонта при его поражении бактериальным эндотоксином липополисахаридом.
\end{abstract}

КЛЮЧЕВЫЕ СЛОВА: пародонтит, хронический гастрит, оксидативный и нитрооксидативный стресс.

O. S. Bedeniuk, M. M. Korda

I. HORBACHEVSKY TERNOPIL STATE MEDICAL UNIVERSITY

\section{ROLE OF OXIDATIVE AND NITROOXIDATIVE STRESS IN PATHOGENESIS OF PERIODONTITIS ON THE CHRONIC GASTRITIS BACKGROUND}

Summary

The aim of the study was to investigate in experiment the biochemical mechanisms of periodontal tissues lipopolysaccharide inflammation on the background of gastric mucosa chronic inflammatory injury. Periodontitis was initiated in white rats by the injection of E. Coli lipopolysaccharide $(40 \mu \mathrm{l}, 1 \mathrm{mg} / \mathrm{ml})$ into gingival tissues. For the modeling of chronic gastritis $2 \%$ sodium salicylate was administered intragastrically for 6 weeks. Lipopolysaccharide periodontitis was accompanied with the increase of TBA-active products and oxidative-modified proteins as well as with the decrease of superoxide dismutase activity and reduced glutathione content in periodontal tissues and blood serum. The total NO synthase activity and $\mathrm{NO}_{x}$ content increased significantly in rats with periodontitis. In animals with both pathologies, periodontitis and chronic gastritis, oxidative and nitrooxidative stress was much more pronounced than in rats without gastritis. It was concluded that chronic gastritis markedly enhances oxidative and nitrooxidative stress in periodontal tissues injured by the bacterial endotoxin lipopolysaccharide.

KEY WORDS: periodontitis, chronic gastritis, oxidative and nitrooxidative stress.

Адреса для листування: О. С. Беденюк, Тернопільський державний медичний університет імені І. Я. Горбачевського, м. Волі, 1 , Тернопіль, 46001, Україна, e-mail: bedenyukos@tdmu.edu.ua. 